\title{
The Linkage between the Degree of Compliance with Corporate Governance Rules and Profitability: Evidence from Palestine Exchange Listed Firms
}

\author{
Dr. Naser Abdelkarim \\ Arab American University, Palestine
}

$\begin{array}{lr}\text { Received: Sep. 10, } 2016 \quad \text { Accepted: Dec. 14, } 2016 \quad \text { Published: January 1, } 2017 \\ \text { doi:10.5296/jmr.v9i1.10003 } & \text { URL: http://dx.doi.org/10.5296/jmr.v9i1.10003 }\end{array}$

\begin{abstract}
The underlying objective of this study is to empirically investigate the relationship between the degree of compliance with the rules of the code of Corporate Governance (CG) that became effective in 2009 and profitability of Palestine Exchange Listed firms. Compliance with CG rules is measured based on a criteria of ten corporate governance indicators identified in the study of Abdelkarim and Ijbarah (2010), while profitability is measured by the percentage of change in ROI reported in year 2008 and its average over the period 2009-2015. The Use of ROI as a dependent variable in this study is based on the theoretical assumption that CG should have positive impact on efficiency in terms of cost management and increase in sales due to increase in market share. Prior research in developed economies reported a significant impact of corporate governance on firm performance particularly if measured as a change in market value. However, in Palestine there was only one study that investigated the relationship between corporate governance measured as the level of ownership concentration and firm's performance measured using Tobin's Q (Abdelkarim and Alawneh, 2005).

Using regression analysis, this study provides empirical evidence that there is no statistically significant relationship between the degree of compliance with the rules in the code of corporate governance and profitability of sample firms. Explanations for this key finding are provided in this study.
\end{abstract}

Keywords: Corporate Governance, Profitability, Return on Investment (ROI), Audited Annual Financial Reports, Disclosure. 


\section{Introduction}

Corporate governance has become an important topic in practice and academic literature in recent years. To ensure a competitive position, to attract capital, to ensure sustainability, to rationalize cost of operations, and to combat corruption; companies from developing countries need to put in consign good governance institutions. According to Monks and Minow (2004) the importance of corporate governance has increased dramatically in 2002 when a series of events led to the bankruptcies of large U.S. companies and the loss of thousands of jobs. The way companies are governed determines their fate as well as that of the economy in general. The investors are attracted to those companies with sound corporate governance practices because, according to OECD (2002), corporate governance specifies the rights and responsibilities among different stakeholders in the company, such as managers, shareholders and creditors, and identifying the rules and procedures for making decisions on company's affairs. In this way, it also provides the structure through which company's objectives are set, the means of attaining those objectives and monitoring performance. Thus, deficiencies in corporate governance may have as a consequence not only scandals and corporate failures but also financial crises and economic instability.

Corporate governance is often defined as the system by which companies are directed and controlled for the benefit of shareholders. Better governance practices allow firms to access capital markets on better terms and can lead to higher firm valuation, and higher rates of return. By mitigating the misalignment of interest among stakeholders; better governance can also reduce the scope for undertaking irrational investment decisions and, therefore, boost growth. The separation of ownership and control in the corporation gives rise to agency problems that have been studied extensively in the theoretical and empirical literature. "Agency problem is the difficulties financiers have in assuring that their funds are not expropriated or wasted on unattractive projects" (Shleifer \& Vishny, 1997, p.741).

The necessity for good corporate governance is addressed from the need for financial funds to maintain the progressively complex nature of company's activities that compete in an integrated world market. In this global economy, in order to attract foreign capital, companies are gradually more concerned with good governance as they need to guarantee that foreign investors' rights are appreciated. Corporate governance is very important for the maximization of the company value as it helps to diminish the cost of foreign financing by ensuring trust among foreign investors .Accordingly, developing and emerging markets have a chance to raise their share of international portfolio investment. Further, Corporate Governance would enhance the operational efficiency of companies via cutting cost and increasing sales. All of these positive effects are expected to lead to higher profitability. In recent years, both national and international authorities have recognized the importance of corporate governance as one element in the quality of a country's financial supervision and the strength of its financial performance. Improvements in corporate governance in many countries have been motivated by high profile failures of significant companies and financial institutions. Corporate governance reform has ranked high on policymakers' agendas in many countries since the late 1990s. New laws and regulations aimed at improving corporate governance have been introduced in many countries. In the case of 
Palestine the code of corporate governance became effective in 2009 by the Palestine Capital Market Authority (PCMA). And there were few studies addressed corporate governance, its relationship with performance, and the degree of compliance by Palestinian listed firms. The distinctiveness of this study will add to the work of other researchers in this field.

\subsection{Purpose of the study}

This study aims at investigating the relationship between the degree of compliance with the code of corporate governance that became effective in 2009 and the profitability of Palestine Exchange Listed firms. Profitability is measured for this purpose as Return on Investment (ROI). In other terms, the key research question of this study is: Has the compliance with code of CG improved rate of ROI of Palestine Exchange listed firms?

The remainder of this paper is organized as follows: Section One reviews and synthesized prior researches in the area of corporate governance. Section two explains the methodology used. Section three discuss and report's findings of the study. Section four offers concluding remarks and future research that may still be warranted in this section.

\section{Literature Review}

Prior research illustrated a significant impact of corporate governance on firms' performance. Developing economies are analyzing extensively the effect of ownership distribution on a firm performance and valuation. As cited by (Shleifer \& Vishny, 1997; Holderness, 2003), separation of ownership and control allows managers to pursue interests that conflict with firm's value maximization. By a common approach to empirical studies in this field, is to focus on the impact of ownership on firm value through a common (D'Souza and Megginson, 1999). According to Shleifer \& Vishny (1997) a major key in resolving the agency problem is by separation of ownership and control or "management and finance" as they called it. "Agency problem is the difficulties financiers have in assuring that their funds are not expropriated or wasted on unattractive projects" (Shleifer \& Vishny, 1997, p.741). However, there is a required change in the optimal size of firms by industrial and technological revolution, which makes a single individual incapable of having sufficient wealth to own a controlling interest, as a result, firms faced "the dissolution of the old atom of ownership into its component parts, control and beneficial ownership" (Berle and Means, 1932, p.8 ).

On the other hand, the literature identifies a non-linear relationship when examining the correlation between a firm's value and internal ownership in emerging economies. [ Demsetz and Villalonga (2001)] thought that even though conceptual and empirical support for the ownership structure, many studies have failed to take this into account estimating the effect of ownership structure on performance.

\section{Corporate Governance Codes and Principles}

Recently, serious efforts to develop corporate governance by establishing international standards have gained huge attention. Most of the regional development banks, such as the World Bank, the Organization of Economic Cooperation and Development and the various 
national development agencies have made severe efforts towards establishing code of corporate governance in the last several years.

The news of falsified practices and company directors in boardrooms at high-profile firms, are questioning the accounting practices and the appearance of excessive managerial compensation at other firms, which is making corporate governance a public debate. In response to the scandals, (DeYoung et. Al., 2005) argued that Sarbanes-Oxley Act of 2002 aimed at improving the quality of audits, enhancing the financial expertise of directors, and increasing the accountability of managers at publicly traded firms. An important relationship between the three key anchors of the firm: shareholders, the board of directors and company management, this relation defined as corporate governance (Wheelen \& Hunger, 2004). This rigid conceptualization is a major key point of the OECD's corporate governance principles issued in the mid-1999 and reviewed in 2004 which are represented under five topics:

\section{1-The Rights of Shareholders and Key Ownership Functions}

The corporate governance framework should protect and facilitate the exercise of shareholders' rights.

\section{2-The Equitable Treatment of Shareholders}

The corporate governance framework should ensure the equitable treatment of all shareholders, including minority and foreign shareholders. All shareholders should have the opportunity to obtain effective redress for violation of their rights

\section{3-The Role of Stakeholders in Corporate Governance}

The corporate governance framework should recognize the rights of stakeholders established by law or through mutual agreements and encourage active co-operation between corporations and stakeholders in creating wealth, jobs, and the sustainability of financially sound enterprises.

\section{4-Disclosure and Transparency}

“The corporate governance framework should ensure that timely and accurate disclosure is made on all material matters regarding the corporation, including the financial situation, performance, ownership, and governance of the company.

\section{5-The Responsibilities of the Board}

"The corporate governance framework should ensure the strategic guidance of the company, the effective monitoring of management by the board, and the board's accountability to the company and the shareholders

\section{The Palestinian Context}

\section{Overview of the Economy}

Thirty years of occupation in the West Bank and Gaza (WBG) has left a seriously imprecise economy in a state that is almost completely dependent on the Israeli economy. While other 
countries in the area have developed and industrialized, the Palestinian economy retains the hallmarks of a less developed economy. After Oslo Accords (September 1993); It was hoped that the Palestinian private sector would take off, Palestinian entrepreneurs would rapidly invest, and the flourishing economy would attract foreign investment. Unfortunately, this did not happen and the economy has suffered even more since Oslo. Growth in the West Bank and Gaza was reasonable after the signing of the Paris Protocol in 1994. Real per capita GDP grew around 3\%. Unemployment rates turned down considerably from nearly 28\% in 1996 to approximately $11 \%$ in 1999.

Prior to the eruption of the Second Intifada in September 2000, the trade between the WBG; and Israel had effectively became domestic, reflecting a customs union regime and majority of Palestinian workers were employed by Israeli firms. The next six years of ascending conflict in the WBG have left the Palestinian economy stuck in catastrophe. It contributed significant declines in investment, employment, and trade resulting into a decline in per capita income of $48 \%$ and in high rates of poverty and unemployment. Following the 2006 public elections the economic crisis became even worse. Real GDP have fallen within a range of 5 to 10 percent in 2006, leaving average real per capita GDP at almost 40 percent below its 1999 level, and unemployment and poverty at totally unprecedented rates. Since 2007 this economy has changed course and witnessed an average growth rate of $6 \%$ per annum. This growth, however, was driven by public spending and not private investment, and was thus characterized as unsustainable and not evenly distributed, leaving poverty and unemployment rates unaffected. More troubling than the negative growth rates over the past few years is the changing composition of the economy, as GDP is being increasingly driven by government and private consumption from remittances and donor aid, while investment has fallen to exceedingly low levels, leaving little productive base for a self-sustaining economy.

\section{Financing}

Financing options are not sufficient enough for the Palestinian private businesses neither in amount nor in variety. The financial system cannot be described as deep, well-functioning or efficient. To the contrary, the financial intermediation through the banking industry has increased in recent years, yet remained low as reflected in the credit to deposits ratio of around 40\% (Palestine Monetary Authority, Annual Report, 2015). .Additionally, more than two thirds of banking credits extended to private businesses have been either in the form of short-term loans or overdrafts, while long- term financing is almost none existent. That clarifies why the Palestinian corporation's capital structure is driven heavily towards equity financing, with extremely low indebtedness (leverage).

The establishment of Palestine Securities Exchange (PSE) in 1997 has provided public shareholdings with new opportunities for long - term equity financing, at a time when banks exercise conservative credit policies when it comes to finance long term investment. Palestinian Capital Market Authority (PCMA) was established in February 2005, in accordance with the Securities Law number 12 for year 2004. The PCMA is the sole legal entity that is responsible for monitoring the trading activities at the PSE as well as for organizing the conduct of the listed companies and the brokerage member firms. The total 
listed firms at the PSE stands now at 49 with market value of around \$2500 million representing only around $20 \%$ of GDP. This low ratio indicates that the role of the PSE in the economy is still far below its potential.

\section{The Private Sector}

The Palestinian Private sector is unique in more than one important aspect. In addition to small and medium family enterprises, poor performance and low governance are a majority in the private sector. The number of relatively large corporations is still too low. More than $95 \%$ of business enterprises are classified as small and medium. Conventionally, the private sector has played a significant role in the development of the Palestinian economy, particularly in absorbing labor force. The majority of firms have traditionally been concentrated in services (restaurants, retail, hotels, and business services) and industry (food and beverage, metal fabrication, textiles $\backslash$ garments and furniture) and private employment is nearly $70 \%$ of the domestic labor force.

\section{The PSE Performance}

PSE's performance has developed over years. Yet, it is still performing under its potential, and it still invites considerable reforms. Policy makers and investors are still concerned with Governance, disclosure and efficiency issues. Another issue is the high degree of ownership concentration in the Palestinian corporations traded. It is widely perceived that this observable fact has been negatively affecting the fair pricing of stocks and therefore weakening confidence in the PSE as a whole. This explains why the PSE continues to lack sufficient depth and liquidity.

Very few studies were conducted to study the corporate governance issue in Palestinian firms. Previous studies of corporate governance of companies in Palestine found that listed corporations compliance with the average corporate governance index is higher than unlisted corporations. Abdelkarim and Alawneh (2008) found some evidence of the relationship between firms' performance as measured by Tobin's Q and corporate governance expressed by ownership concentration, they argued that ownership concentration is negatively related to firm's value.

The interests of stockholders in publicly traded firms to establish a good corporate governance structure consists largely of three major bodies. First, corporate board of directors, who oversight and monitors the activities of the company's management, Second, the PCMA along with the PSE which issued a disclosure code of conduct in 2006, as well as undertaking considerable efforts of establishing codes of corporate governance in Palestine. The PSE, in cooperation with the PCMA, regulates and manages trade transactions of listed stocks on the basis of fairness and minority interest protection.

\section{Research Methodology}

\subsection{Objective and Hypothesis}

As stated earlier, this study aims at investigating the relationship between the degree of compliance with the code of corporate governance that became effective in 2009 and 


\section{Macrothink

performance of Palestine Exchange Listed firms. Compliance to corporate governance is measured based on a criteria of ten corporate governance factors identified in the study of Abdelkarim and Ijbarah (2010). Performance, on the other hand, is measured by the percentage of change in ROI between the year 2008 (prior to enactment of Corporate Governance Code) and the average ROI over the period 2009- 2015.

The hypothesis of the study is stated in null form as follows:

Ho1: There is no impact of level of compliance with the Code of Corporate Governance and ROI of PSE listed firms. Namely, there is no statistically significant difference between the ROI of firms that comply with the Code of corporate governance and the ones that don't.

\subsection{Population and sample}

The population of this study is all the companies listed at $t$ PSE and they are 49 companies. We excluded banks since the Banking Law number 2, 2002, that was issued by the Palestinian Monetary Authority has already imposed corporate governance rules on banks operating in the Palestinian Territories. These rules were even tightened by the recent amendment of law issued in 2011. We also excluded all the companies listed in 2009 and thereafter, and they are 10 companies, since the code of corporate governance became effective only in 2009. And finally two suspended companies were excluded. Thus study sample is formed of 28 companies that represent $61 \%$ of the population.

\subsection{Data gathering}

For analysis purposes profitability was measured using the Return on Investment indicator (ROI). Thus, calculation of Profit Margin (NI/ SALES) and asset Turnover (NET SALES/ NET ASSETS) was made for both samples for the years 2008- 2015.

Then the ROI was calculated by multiplying the Margin with the Turnover.

Table 1 below presents the ROI for the year 2008 and the average over 2009-2015 for all sample firms 


\section{Macrothink}

Table 1. Classification of sample firms based on level of CG Compliance and ROI data

\begin{tabular}{|c|c|c|c|}
\hline Company & Classification & ROI 2008 & Average ROI 2009-2015 \\
\hline 1 & high degree of compliance & 0.025704574 & 0.000748926 \\
\hline 2 & high degree of compliance & 0.193051026 & 0.156615469 \\
\hline 3 & high degree of compliance & 0.045680865 & 0.054454843 \\
\hline 4 & low degree of compliance & 0.035559443 & 0.033624231 \\
\hline 5 & low degree of compliance & 0.001838771 & 0.000828472 \\
\hline 6 & low degree of compliance & 0.094817733 & 0.060257961 \\
\hline 7 & low degree of compliance & -0.018970321 & 0.094857572 \\
\hline 8 & high degree of compliance & 0.064868132 & 0.070653936 \\
\hline 9 & low degree of compliance & 0.085374281 & 0.169 \\
\hline 10 & high degree of compliance & 0.015362379 & 0.025898142 \\
\hline 11 & high degree of compliance & 0.043325064 & \\
\hline 12 & low degree of compliance & 0.087608316 & 0.032714096 \\
\hline 13 & low degree of compliance & 0.104390563 & 0.177915914 \\
\hline 14 & low degree of compliance & 0.001462828 & 0.036579765 \\
\hline 15 & low degree of compliance & 0.067180362 & 0.011129283 \\
\hline 16 & low degree of compliance & 0.051380014 & -0.144703866 \\
\hline 17 & high degree of compliance & 1 & 0.147395857 \\
\hline 18 & low degree of compliance & 0.092452324 & 0.109041821 \\
\hline 19 & low degree of compliance & 0.032897891 & 0.040554951 \\
\hline 20 & high degree of compliance & -0.11383943 & -0.073021836 \\
\hline 21 & low degree of compliance & -0.015286013 & -0.115726852 \\
\hline 22 & high degree of compliance & -0.100484312 & 0.026087084 \\
\hline 23 & high degree of compliance & 0.047130866 & 0.075189393 \\
\hline 24 & low degree of compliance & 0.074 & 0.075 \\
\hline 25 & high degree of compliance & -0.034578418 & -0.033509367 \\
\hline 26 & low degree of compliance & -0.035 & -0.034 \\
\hline 27 & low degree of compliance & -0.066120337 & 0.060872485 \\
\hline 28 & high degree of compliance & 0.05945424 & 0.038675118 \\
\hline
\end{tabular}

Sample companies were classified into two groups; companies with high degree of compliance with the Code of Corporate Governance, and companies with low degree of compliance with the Code of Corporate Governance. Classification was made based on the criteria specified in evidence on corporate governance compliance by Palestine securities exchange listed firms (Abdelkarim and Ijbarah, 2010). This parameter is formed of 10 factors that are highly related to corporate governance and they are:

1. Shareholders are provided with adequate information about meetings

2. Shareholders priority subscription rights are protected 


\section{Macrothink}

3. Enough information about major shareholders' ownership

4. Disclosure about best practices

5. Financial statements disclosure

6. Better disclosure about the board of directors' activities

7. Qualified independent directors

8. Separating the CEO from the board chairman position

9. Formal annual evaluation of the board of directors and the directors

10. Formal CEO evaluation

Based on the above criteria, sample companies which get 6 or above out of ten are classified as companies with high level of compliance. And companies which get less than 6 are classified as companies with low level of compliance. The classification is shown in table 2 below:

Table 2. Classification of Palestinian listed companies in terms of level of compliance with Code of Corporate Governance

\begin{tabular}{|l|r|r|}
\hline \multicolumn{1}{|c|}{ classification } & \multicolumn{2}{|c|}{ percentage of total } \\
\hline companies with high degree of compliance & 13 & $46 \%$ \\
\hline companies with low degree of compliance & 15 & $54 \%$ \\
\hline total & $\mathbf{2 8}$ & $\mathbf{1 0 0 \%}$ \\
\hline
\end{tabular}

Table 2 shows that 13 companies representing 45\%, of sample have high degree of compliance to corporate governance. While 15 companies, 55\%, have low degree of compliance to corporate governance

\section{Hypothesis Testing}

Based on data gathered for sample firms the percentage of change in ROI between the years 2008 and 2010 is calculated, required calculations are illustrated in the table 3 below: 
Table 3. percentage of change in ROI between 2008 and 2015

\begin{tabular}{|c|c|}
\hline Company & $\begin{array}{l}\text { Percentage of } \\
\text { change in ROI }\end{array}$ \\
\hline 1 & -0.98 \\
\hline 2 & -0.19 \\
\hline 3 & 0.19 \\
\hline 4 & -1.95 \\
\hline 5 & 5.71 \\
\hline 6 & -0.27 \\
\hline 7 & -2.37 \\
\hline 8 & 0.07 \\
\hline 9 & -0.83 \\
\hline 10 & 0.90 \\
\hline 11 & 0.38 \\
\hline 12 & -0.62 \\
\hline 13 & 0.72 \\
\hline 14 & 24.01 \\
\hline 15 & -0.83 \\
\hline 16 & -3.82 \\
\hline 17 & 2.02 \\
\hline 18 & 0.18 \\
\hline 19 & 0.23 \\
\hline 20 & -0.36 \\
\hline 21 & 6.57 \\
\hline 22 & -1.26 \\
\hline 23 & 0.62 \\
\hline 24 & 7.73 \\
\hline 25 & -0.03 \\
\hline 26 & 0.27 \\
\hline 27 & -1.92 \\
\hline 28 & -0.35 \\
\hline
\end{tabular}

Regression analysis of the relationship between the degree of compliance for the sample listed firms with the code of corporate governance and profitability measured by the change in ROI was calculated. Table 4 below shows the regression results. 
Table 4. Regression Analysis Results

\begin{tabular}{|c|c|c|c|}
\hline Model & Sum of Squares & Mean Square & Sig. \\
\hline 1 Regression & 26.491 & 26.491 & $.325^{\mathrm{a}}$ \\
\hline Residual & 682.941 & 26.267 & \\
\hline Total & 709.432 & & \\
\hline
\end{tabular}

The results show that there is no statistically significant relationship between the degree of compliance with the code of corporate governance and percentage of change in ROI. Therefore, the null hypothesis of the study is accepted.

This result may be explained in the framework of the following information:

1. The time lag between the issuance of the Code and the study timeframe may not have been long enough to allow for the capitalization of the impact of compliance with the Code.

2. The Palestinian economic environment and performance has been unstable over years; thus, regardless of compliance to corporate governance rules, uncontrolled economic factors may have had stronger effect on firms' performance.

\section{Conclusions and Further Research}

Corporate governance has become an important topic in practice and academic literature in recent years. To ensure a competitive position, to attract capital, to ensure sustainability, and to combat corruption; companies from developing countries need to put in consign good governance institutions. This study aims at investigating the relationship between the degree of compliance with the code of corporate governance that became effective in 2009 and performance of Palestine Exchange Listed. Profitability was measured using the Return on Investment indicator (ROI). ROI was calculated as a multiplication of Net income over Sales (NI/ SALES) and asset Turnover (NET SALES/ ASSETS). And since the results show that there is no empirical relationship between the degree of compliance with the Code of Corporate Governance and ROI, it encourages further research to investigate a more specific relationship between the degree of compliance to corporate governance and other independent variables such as Net income over Sales, assets Turnover, and profit margin (gross profit/net sales.

\section{References}

Abdelkarim, N., \& Alawneh, S. (2008). The Relationship between Ownership Concentration and Corporate Performance in Palestine: Empirical Evidence in Supporting of Change. International Journal of Business and Finance Research, 3(2).

Abdelkarim, N., \& Ijbara, k. (2010). Evidence on Corporate Governance Compliance by Palestanian Securities Exchange Listed Firms. Global Journal of business firms.

Abdelkarim, N. (2007). Assessment of Listing and Disclosure Experience of the Palestinian Securities Exchange. Paper Presented at the First Annual Forum of Capital Market, Ramallah, Palestine, September 8-10. 
Abdelkarim, N. (1995). Empirical Assessment of Economic Viability of Establishing Palestine Securities Exchange. Deanship of Research, Al-Najah National University, Nablus, Palestine.

Abdul Kadir, A. (1999). The Corporate Governance trends in Malaysia. February Finance committee Report on Corporate Governance, Securities Commission Malaysia, Kuala Lumpur.

Berle, Adolf A., Jr., \& Gardner C. Means. (1932). The Modern Corporation and Private Property. New York: MacMillan.

Bujaki, M. I. and Richardson, A. J. (1997). A Citation Trial Review of the Uses of Firm Size in Accounting Research. Journal of Accounting Literature, 19, 1-27.

De Young, R. Driscoll, P., \& Fried, CA. (2005). Corporate Governance at Community Banks: A seventh District Analysis. The Federal Reserve Bank of Chicago, Chicago Federal Letter No. 219

Gourevitch, P.A., \& Shinn, J. (2005). Political Power and Corporate Governance: The New Global Politics of Corporate Governance, Princeton University Press, Princeton, NJ.

Harris, D., \& Helfat, C. E. (1998). CEO Duality, Succession, capabilities and Agency theory: Commentary and Research Agenda. Strategic Management Journal, 19(9), 901- 904. https://doi.org/10.1002/(SICI)1097-0266(199809)19:9<901::AID-SMJ2>3.0.CO,2-V

Hart, O. (1995). Corporate Governance: Some Theory and Implications. The Economic Journal, 105(430), 678-689. https://doi.org/10.2307/2235027

Helbling, C., \& Sullivan, J. (2002). Introduction: Instituting Corporate Governance in Developing, Emerging and Transitional Economies, A Handbook, Center for International Private Enterprise (CIPE), Washington, D.C.

Holderness, Clifford G. (2003). A Survey of Blockholders and Corporate Control. Economic Policy Review, 9(1), April. https://doi.org/10.2139/ssrn.281952

Kabaja, A. and others (2008). Enhancement of Corporate Governance in Palestine. the Palestine Economic Policy Research Institute MAS, Ramallah, Palestine.

La Porta, R., Lopez-de-Silanes, F., \& Shleifer, A. (1999). Corporate Ownership Around the World. Journal of Finance, 54, 471-5 17.

Nam, SW., \& Nam, IL. Chong. (2004). Corporate governance in Asia: Recent Evidence from Indonesia, Republic of Korea, Malaysia, and Thailand. Unpublished manuscript, Asian Development Bank Institute, Tokyo.

Organization for Economic Co-operation and Development. (2004). OECD Principles of Corporate Governance. OECD, Paris.

Shleifer, A., \& Vishny, R. W. (1997). A Survey of Corporate Governance. Journal of Finance, 52, 737-783. https://doi.org/10.1111/j.1540-6261.1997.tb04820.x

Wheelen, T., \& Hunger, J. (2004). Strategic management, \& Business Policy, (9th ed.), New Jersey: prentice Hall. 